\title{
Management of orbital fractures in adolescents. Review and case report of three different techniques
}

Manejo das fraturas orbitárias em adolescentes. Revisão e relato de caso de três differentes técnicas

Tratamiento de las fracturas orbitarias en adolescentes. Revisión y reporte de casos de tres técnicas diferentes

Received: 04/22/2021 | Reviewed: 04/30/2021 | Accept: 05/12/2021 | Published: 05/28/2021

Bruna da Fonseca Wastner ORCID: https://orcid.org/0000-0002-9056-3733 Erasto Gaertner Cancer Center, Brazil Universidade Federal do Paraná, Brazil E-mail: bucobw@gmail.com

William Phillip Pereira da Silva ORCID: https://orcid.org/0000-0003-4172-7217 Erasto Gaertner Cancer Center, Brazil São Paulo State University, Brazil E-mail: william_phillip@ hotmail.com

Veridiane Walter Luscinski Dissenha ORCID: https://orcid.org/0000-0002-6506-9303 Positivo University, Brazil E-mail: veridianewalter@hotmail.com

Mara Albonei Dudeque Pianovski ORCID: https://orcid.org/0000-0003-0260-8506 Erasto Gaertner Cancer Center, Brazil Federal University of Paraná, Brazil E-mail:mpianovski@erastogaertner.com.br

Leonardo Faverani

ORCID: https://orcid.org/0000-0003-2249-3048 São Paulo State University, Brazil E-mail: leonardo.faverani@unesp.br

José Luis Dissenha

ORCID: https://orcid.org/0000-0001-8059-183X Erasto Gaertner Cancer Center, Brazil E-mail: jldissenha@ig.com.br

\begin{abstract}
The management of orbital fractures in children and adolescents is little reported in the literature, considering that orbital fractures can cause functional problems such as enophthalmia, diplopia and aesthetic deformities. The aim of this study is to review the literature and report three clinical cases, corroborating with professional experience, about the different management of orbital fractures in adolescents, approaching the advantages, disadvantages and complications. Among the different fractures of the orbital floor, the techniques of interposition of autograft of the anterior wall of the maxillary sinus, suture for anchoring the periosteum, and reduction and stabilization of the fracture by means of titanium mesh fixation were performed. The choice of material and technique depends on the surgeon's preference, access and availability of materials. Regardless of which technique and material is used, and complete removal of the herniated tissue is fundamental to obtain satisfactory results.
\end{abstract}

Keywords: Orbital fractures; Orbit; Pediatrics; Allograft; Surgical meshes.

\section{Resumo}

O manejo das fraturas orbitais em crianças e adolescentes, são pouco relatadas na literatura, considerando que as fraturas orbitais podem ocasionar problemas funcionais como enoftalmia, diplopia e deformidades estéticas. Objetivando revisar a literatura e relatar três casos clínicos, corroborando com a experiencia profissional, sobre diferentes manejos de fraturas orbitárias em adolescentes, abordando as vantagens, desvantagens e complicações. Dentre as diferentes fraturas de assoalho orbitário, foi realizado as técnicas de interposição de enxerto autógeno de parede anterior de seio maxilar, a sutura de ancoragem do periósteo e a redução e estabilização da fratura através da fixação de tela de titânio. A escolha do material e técnica dependem da preferência do cirurgião, do acesso e da disponibilidade dos materiais. Independente de qual técnica e material seja utilizado, e a remoção completa do tecido herniado é fundamental para a obtenção de resultados satisfatórios.

Palavras-chave: Fraturas orbitárias; Órbita; Pediatria; Aloenxerto; Telas cirúrgicas. 


\section{Resumen}

El manejo de las fracturas orbitarias en niños y adolescentes está poco reportado en la literatura, considerando que las fracturas orbitarias pueden causar problemas funcionales como enoftalmia, diplopía y deformidades estéticas. Nuestro objetivo es revisar la literatura y reportar tres casos clínicos, corroborando con la experiencia profesional, sobre los diferentes manejos de las fracturas orbitarias en adolescentes, abordando las ventajas, desventajas y complicaciones. Entre las diferentes fracturas del suelo orbitario, realizamos las técnicas de interposición de autoinjerto de la pared anterior del seno maxilar, la sutura para el anclaje del periostio y la reducción y estabilización de la fractura mediante la fijación de malla de titanio. La elección del material y de la técnica depende de la preferencia del cirujano, del acceso y de la disponibilidad de los materiales. Independientemente de la técnica y el material que se utilicen, es esencial eliminar por completo el tejido herniado para obtener resultados satisfactorios.

Palabras clave: Fracturas orbitales, Órbita, Pediatría; Aloinjertos; Mallas quirúrgicas.

\section{Introduction}

Orbital trauma can cause several functional disorders such as enophthalmia and diplopia, as well as aesthetic deformities. Despite this, studies about these types of fractures and surgical interventions in children and adolescents are still scarce (Wei \& Durairaj, 2011). Children have some natural protective factors, especially those younger than 7 years old, such as thicker sinus walls, a greater bone elasticity, a greater amount of cheek fat, and a proportionally smaller and flatter facial middle third (Hink \& Durairaj, 2013; Koltai et al., 1995). When this type of fracture occurs, therefore, it is usually related to low-velocity, high-force trauma (Grant 3rd et al., 2002), caused by sports and automotive accidents, and assaults (Chi et al., 2010; Heggie et al., 2015).

The evolution of guidelines in adult patients with orbital fractures is constant. However, little has been achieved in the pediatric population, with a limited amount of information on surgical and non-surgical indications, the timing of the approach and techniques indicated, which ultimately leads the surgeon to choose one or another option based on his preferences and previous experiences (Gerbino et al., 2010; Heggie et al., 2015; Wei \& Durairaj, 2011).

There are several surgical approaches for repairing an orbital floor fracture, ranging from the type of access to the options of materials and techniques for orbital floor reconstruction (Cobb et al., 2013). However, each method brings with it advantages, disadvantages and possible complications that must be taken into account for the decision of the treatment, considering the age of the patient being treated and the growth phase in which he or she is, in addition to the severity of the fracture (Gerbino et al., 2010; Wei \& Durairaj, 2011).

Therefore, this study aims to review the literature on three different techniques for the management of orbital fractures in adolescents, discussing the advantages, disadvantages, and complications, based on professional experience exemplified by a technical review of three clinical cases.

\section{Methodology}

This is a retrospective, descriptive and observational study in the format of a technical note, presenting three clinical cases of orbital fractures in adolescents treated with different techniques. The epidemiological data, history of the disease and photographic records were collected from physical records, after authorization from the patients, by means of the informed consent form (ICF), following the precepts for publication without the identification of the study patients. To complement and substantiate the article, searches were made in the current literature using descriptors from the MeSH Database through the keywords: Orbital Fractures; Orbit; Pediatrics; Allograft; Surgical Meshes. The data were searched using the following platforms: Pubmed; Embase; Scopus and Periódicos CAPES. Based on the results found, a brief review and discussion on the theme were performed. 


\section{Report Cases}

Three male patients with fractures of the orbital floor were selected through a review of medical records. One case of trapdoor fracture in a 12-year-old boy (Case 1), one correction of sequelae after conservative treatment in a 14-year-old young male (Case 2), and one comminuted fracture in a 16-year-old teenager (Case 3). All three patients underwent surgery to release herniated tissues in the maxillary sinus, through transcutaneous access performed by the same surgeon and were monitored for 12 months.

\section{Case 1}

Male patient, 12 years old, victim of a bicycle accident with direct trauma to the right eyeball against the handlebars. The patient had an edema in the right orbital region, pain in the right eye and paresthesia in the right midface, with some episodes of vomiting. CT scan confirmed trapdoor orbital fracture with fat entrapment. The patient was treated surgically on the second day after trauma. A transcutaneous access was chosen and after the release of the incarcerated fat tissue, a $1 \times 1 \mathrm{~cm}$ block of bone graft harvest from the ipsilateral maxillary sinus wall was placed on the floor of the orbit. It was decided not to fix the graft and to keep it in position only with the weight of the eyeball. Internal and skin sutures were performed, ending with an occlusive dressing. The patient was discharged the day after the procedure, painless and with no new episodes of vomiting. One year after the surgery, the patient remains well and without complaints.

\section{Case 2}

Male patient, 14-year-old, with a history of orbital trauma 8 months before, complaining of paralysis in his right eye and double vision. Preview doctors in a different hospital opted for a conservative approach, which led to a vertical diplopia and limitation of eye movement when looking up. Enophthalmos was not observed. CT scan showed blow out fracture in the right orbit, with herniation of fat and muscle tissue. The patient was admitted and referred for surgical correction. A transcutaneous access was chosen and after the release of the incarcerated tissue, it was performed an anchorage suture of the periosteum with 4-0 Vycril to obliterate the gap, creating a base to prevent further herniation. Internal and skin sutures were performed, ending with an occlusive dressing. The patient was discharged the day after the procedure, with no pain complaints and physiotherapy instructions to improve eye movements and strengthen the inferior rectus muscle. One year after surgery, the patient remains well, with partial recovery of the upper right eye movement and minimal scarring in the region.

\section{Case 3}

Male patient, 16-year-old male, victim of physical aggression. On examination, there was hematoma and extensive edema on the bilateral periorbital and nasal dorsum, with preserved visual acuity and ocular mobility. After partial regression of the edema, 2 days after the trauma, the patient began to present diplopia in the right eye and difficulty in moving it laterally. CT scan showed blow out fracture of the right orbit, with herniation of fat and muscle tissue. The patient was submitted to surgical treatment on the sixth day after trauma. A transcutaneous access was chosen and after the release of the incarcerated tissue, a titanium mesh was placed and fixed with two $5 \mathrm{~mm}$ screws, 1.5 system, to restore the orbital floor. The patient was discharged on the next day and returned to follow-up appointments without complaints of diplopia and with complete recovery of the right eye movement.

Regarding surgical timing, Case 1 underwent surgery in the first 24 hours after trauma due to evidence of oculocardiac reflex; Case 2, who presented motor deficit in the right eye, was referred to us only 9 months after trauma; Case 3 underwent surgery on the sixth day after trauma when there was sufficient regression of the edema. 
About the techniques adopted in each patient, in summary: Case 1 had the floor of the orbit occluded with $1 \mathrm{~cm} 2$ autogenous graft harvested from the anterior wall of the maxillary sinus without rigid fixation, due to the fact that it was a trapdoor fracture, without displacement; In Case 2 it was decided to perform an anchoring suture of the periosteum and fat pad in order to obliterate the incarceration region and serve as a base to avoid new herniation since it was an old fracture with considerable tissue fibrosis; Case 3, for presenting a comminuted fracture, received titanium mesh fixed with two 5mm screws of 1.5 system.

Regarding the results, success was achieved in all techniques at 1 year of follow-up. Case 1 and Case 3 showed complete recovery, without diplopia or residual paralysis, with minimal scarring on the skin of the infraorbital region and without ectropion. Case 2, despite the decarceration of the inferior rectus muscle and physical therapy, had partial recovery of upper right eye movement, which was expected due to the long time the muscle remained trapped.

\section{Discussion}

Orbital floor fractures in young patients commonly appear differently than in adult patients and can have major longterm consequences if not correctly diagnosed and treated (Wei \& Durairaj, 2011).

There are some subclassifications within the orbital floor fractures, but one that draws attention in the pediatric population is the trapdoor type, which consists of a minimally displaced linear trace that follows the infraorbital foramen (Soll \& Poley, 1965). This fracture is difficult to visualize on radiographic examinations, and thin-slice CT scans in coronal and sagittal views are required for proper visualization. Although small and without clinical significance, this type of fracture is related to compartment syndrome around the inferior rectus muscle, resulting in ischemia and potentially permanent sequelae if treatment is not performed early (De Man et al., 1991; Smith et al., 1984). Two common clinical presentations that help to guide this diagnosis are the "white-eye" fracture and the oculocardiac reflex (Wei \& Durairaj, 2011). "White-eye" fracture is seen when the patient has a history of orbital trauma and/or diagnosed fracture, but with minimal or even no clinical changes such as edema, enophthalmia, and conjunctival signs, and may have negative or inconclusive imaging tests (Jordan et al., 1998). Often, only vertical diplopia or ophthalmoplegia is present (Jordan et al., 1998). The literature has shown that patients with this presentation who undergo surgery within the first 48 hours after trauma have a better chance of eye movement recovery than those who have waited 2 weeks (Grant 3rd et al., 2002; Jordan et al., 1998). The oculocardiac reflex consists of a triad of symptoms (nausea/vomiting, bradycardia, and syncope) that results from communication between the ophthalmic trigeminal ramus and the vagus motor nucleus, representing an indication for immediate correction (Cobb et al., 2009; Kim et al., 2010; Sires et al., 1998).

Imaging exams should be requested when there is a hypothesis of fracture of the orbital complex, raised through the physical exam and the patient's complaints. Changes that raise attention for this diagnosis are crepitation, visible deformity, altered ocular mobility and/or visual acuity, severe pain, proptosis, enophthalmos, extrusion of eyeball contents, increased intercanthal distance, and oculocardiac reflex (Chapman et al., 2009; Sires et al., 1998). Specifically, in-floor fractures, fewer changes are seen, especially in the pediatric population, often being limited to ocular mobility changes and diplopia, mild enophthalmia, and the presence of an oculocardiac reflex (Bansagi \& Meyer, 2000; Cobb et al., 2009; Cohen \& Garrett, 2003). Performing scans when there is no clear suspicion of fracture should be discouraged, avoiding unnecessary radiation exposure. When it is indicated, however, the choice should be for high-resolution thin-section computed tomography, since common radiographs do not add much information in these cases. Nuclear magnetic resonance imaging is indicated in cases where there is a high suspicion of fracture with tissue entrapment that CT scan could not detect, due to its high cost (Cobb et al., 2013; Wei \& Durairaj, 2011). 
Regarding the timing for surgical repair, it seems that the most appropriate is to approach cases with diplopia, ophthalmoplegia, and soft tissue entrapment confirmed by imaging between 1 and 5 days, and better results are expected if the procedure is performed within the first 48 hours after trauma, especially if facing a trapdoor fracture (Grant 3rd et al., 2002; Jordan et al., 1998).

Surgical treatment aims to release the herniated structures and protect the fractured floor so that the herniation does not recur, which can be performed with many techniques. Regarding surgical access, transcutaneous, transconjunctival, subciliary or transantral access with endoscopic visualization can be used. All options are well established in the literature, with advantages and disadvantages, and the decision is based on the surgeon's preference and the availability of equipment, as in the case of transantral access. Most articles show a preference for transconjunctival access, which demonstrates good visualization and space for tissue manipulation (Cobb et al., 2013; Waite \& Carr, 1991). Subciliary access is more indicated in cases where the fracture extends medially (Cobb et al., 2013). In the cases discussed in this article, transcutaneous access was preferred, which is routine for the team, with a high success rate and minimal scarring, as well as reducing the risk of damage to the eyeball, since this access is more distant.

Regarding floor reconstruction, a systematic review showed that the most commonly used materials are porous polyethylene, autogenous bone, dura mater, silicone, fluorocarbon polymers, and gelatin film (Avashia et al., 2012). Autogenous bone graft has been considered the gold standard when compared to other biomaterials in the repair of orbital floor fractures (Schlickewei \& Schlickewei, 2007). The most common sites for harvesting are the iliac bone, rib, and calvaria (Avashia et al., 2012; Zimmermann et al., 2005). The advantages of this technique are low cost, variability in thickness, maximum biocompatibility, and radiopacity (Burchardt, 1983). The main disadvantage associated with autogenous bone grafts is the need for a donor area and the morbidity related to the harvesting of the material (Stam et al., 2014). The use of grafting from the anterior maxillary sinus wall, performed in Case 1, minimizes the issue of extra morbidity because the harvest site is in the same location that is being operated on. Personally, the authors do not agree with harvesting grafts from the calvaria, rib, and iliac for small defects, which can be treated with smaller and local grafts. The periosteal anchoring suture with adipose tissue performed in Case 2 was enough to obliterate the fracture and avoid new herniation, being a case of a small defect. Other authors prefer the use of alloplastic materials, mainly polyethylene, to avoid a second surgery, as the material becomes incorporated into the adjacent fibrovascular tissue (Theologie-Lygidakis et al., 2007). This is a difficulty in public health services, which rarely have these options available, so the use of these materials was not considered in the reported cases. Another option is the use of non-absorbable alloplastic materials such as titanium mesh, which is a thin and malleable material that contours the orbit wall, maintaining its shape and is easily stabilized, but with the disadvantage of having to be removed in patients still in the growth phase (Ellis III \& Tan, 2003). This material is more commonly found and is often the only option besides autogenous grafts in many public health institutions. In Case 3, the titanium mesh was chosen due to the greater complexity of the fracture and the older age of the patient, considering that the growth peak had already passed.

\section{Conclusion}

The comparison of the literature with the cases briefly reported and the techniques used, demonstrate that the choice of material and technique depends on the preference of the surgeon. Considering the advantages and disadvantages of each material/technique, the access and availability of materials at the site of care, as well as the personal confidence to perform one or another procedure, favors the results, obtaining a correct positioning and a better resolution of the case. Independent of which technique and material are used, the complete removal of the herniated tissue is fundamental to obtain satisfactory results. 


\section{References}

Avashia, Y. J., Sastry, A., Fan, K. L., Mir, H. S., \& Thaller, S. R. (2012). Materials used for reconstruction after orbital floor fracture. Journal of Craniofacial Surgery, 23(7), S49-S55.

Bansagi, Z. C., \& Meyer, D. R. (2000). Internal orbital fractures in the pediatric age group: characterization and management. Ophthalmology, 107(5), 829836.

Burchardt, H. (1983). The biology of bone graft repair. Clinical orthopaedics and related research(174), 28-42.

Chapman, V. M., Fenton, L. Z., Gao, D., \& Strain, J. D. (2009). Facial fractures in children: unique patterns of injury observed by computed tomography. Journal of computer assisted tomography, 33(1), 70-72.

Chi, M. J., Ku, M., Shin, K. H., \& Baek, S. (2010). An analysis of 733 surgically treated blowout fractures. Ophthalmologica, 224(3), 167-175.

Cobb, A., Murthy, R., Manisali, M., Uddin, J., \& Toma, A. (2009). Oculovagal reflex in paediatric orbital floor fractures mimicking head injury. Emergency Medicine Journal, 26(5), 351-353.

Cobb, A. R., Jeelani, N. O., \& Ayliffe, P. R. (2013). Orbital fractures in children. British Journal of Oral and Maxillofacial Surgery, 51 (1), 41-46.

Cohen, S. M., \& Garrett, C. G. (2003). Pediatric orbital floor fractures: nausea/vomiting as signs of entrapment. Otolaryngology-Head and Neck Surgery, $129(1), 43-47$.

De Man, K., Wijngaarde, R., Hes, J., \& De Jong, P. (1991). Influence of age on the management of blow-out fractures of the orbital floor. International journal of oral and maxillofacial surgery, 20(6), 330-336.

Ellis III, E., \& Tan, Y. (2003). Assessment of internal orbital reconstructions for pure blowout fractures: cranial bone grafts versus titanium mesh. Journal of Oral and Maxillofacial Surgery, 61(4), 442-453.

Gerbino, G., Roccia, F., Bianchi, F. A., \& Zavattero, E. (2010). Surgical management of orbital trapdoor fracture in a pediatric population. Journal of Oral and Maxillofacial Surgery, 68(6), 1310-1316.

Grant 3rd, J. H., Patrinely, J. R., Weiss, A. H., Kierney, P. C., \& Gruss, J. S. (2002). Trapdoor fracture of the orbit in a pediatric population. Plastic and reconstructive surgery, 109(2), 482-489; discussion 490.

Heggie, A., Vujcich, N., Shand, J., \& Bordbar, P. (2015). Isolated orbital floor fractures in the paediatric patient: case series and review of management. International journal of oral and maxillofacial surgery, 44(10), 1250-1254.

Hink, E. M., \& Durairaj, V. D. (2013). Evaluation and treatment of pediatric orbital fractures. International ophthalmology clinics, 53(3), 103-115.

Jordan, D., Allen, L., White, J., Harvey, J., Pashby, R., \& Esmaeli, B. (1998). Intervention within days for some orbital floor fractures: the white-eyed blowout. Ophthalmic plastic and reconstructive surgery, 14(6), 379-390.

Kim, J., Lee, H., Chi, M., Park, M., Lee, J., \& Baek, S. (2010). Endoscope-assisted repair of pediatric trapdoor fractures of the orbital floor: characterization and management. Journal of Craniofacial Surgery, 21(1), 101-105.

Koltai, P. J., Amjad, I., Meyer, D., \& Feustel, P. J. (1995). Orbital fractures in children. Archives of Otolaryngology-Head \& Neck Surgery, 121(12), 13751379 .

Schlickewei, W., \& Schlickewei, C. (2007). The use of bone substitutes in the treatment of bone defects-the clinical view and history. Macromolecular Symposia,

Sires, B. S., Stanley, R. B., \& Levine, L. M. (1998). Oculocardiac reflex caused by orbital floor trapdoor fracture: an indication for urgent repair. Archives of ophthalmology, 116(7), 955-956.

Smith, B., Lisman, R. D., Simonton, J., \& Della Rocca, R. (1984). Volkmann's contracture of the extraocular muscles following blowout fracture. Plastic and reconstructive surgery, $74(2), 200-216$.

Soll, D. B., \& Poley, B. J. (1965). Trapdoor Variety of Blowout Fracture of the Orbital Floor . American journal of ophthalmology, 60(2), 269-272.

Stam, L. H., Kesselring, A. G., Promes, P., van der Wal, K. G., \& Koudstaal, M. J. (2014). Morbidity of harvesting the iliac crest inner cortical plate for orbital reconstruction. Journal of Oral and Maxillofacial Surgery, 72(7), 1339-1342.

Theologie-Lygidakis, N., Iatrou, I., \& Alexandridis, C. (2007). Blow-out fractures in children: six years' experience. Oral Surgery, Oral Medicine, Oral Pathology, Oral Radiology, and Endodontology, 103(6), 757-763.

Waite, P. D., \& Carr, D. D. (1991). The transconjunctival approach for treating orbital trauma. Journal of Oral and Maxillofacial Surgery, 49(5), 499-503.

Wei, L. A., \& Durairaj, V. D. (2011). Pediatric orbital floor fractures. Journal of American Association for Pediatric Ophthalmology and Strabismus, 15(2), 173-180.

Zimmermann, C., Troulis, M., \& Kaban, L. (2005). Pediatric facial fractures: recent advances in prevention, diagnosis and management. International journal of oral and maxillofacial surgery, 34(8), 823-833. 